\title{
Host intestinal biomarker identification in a gut leakage model in broilers
}

\author{
Fien De Meyer ${ }^{1}$, Venessa Eeckhaut ${ }^{1}$, Richard Ducatelle1, Maarten Dhaenens², Simon Daled², \\ Annelike Dedeurwaerder ${ }^{3}$, Maarten De Gussem ${ }^{3,4}$, Freddy Haesebrouck', Dieter Deforce ${ }^{2}$ \\ and Filip Van Immerseel ${ }^{1 *}$
}

\begin{abstract}
Intestinal health problems are a major issue in the poultry industry. Quantifiable easy-to-measure biomarkers for intestinal health would be of great value to monitor subclinical intestinal entities that cause performance problems and to evaluate control methods for intestinal health. The aim of the study was to identify host protein biomarkers for intestinal inflammation and intestinal barrier damage. Proteomic analysis was conducted on ileal and colonic content samples of broilers under an experimental gut damage and inflammation model. Effects of the challenge treatment resulted in a worse gut condition based on macroscopic gut appearance $(p<0.0001)$. Also microscopic changes such as shortening of the villi and increased crypt depth $(p<0.0001)$ as well as higher infiltration of T-lymphocytes $(p<0.0001)$ were seen in the duodenal tissue of challenged animals. Several candidate proteins associated with inflammation, serum leakage and/or tissue damage were identified with an increased abundance in intestinal content of challenged animals $(p<0.05)$. Conversely, brush border enzymes were less abundant in intestinal content of challenged animals $(p<0.05)$. These candidate biomarkers have potential to be used in the field for detection of gut barrier failure in broilers.
\end{abstract}

\section{Introduction}

The production and consumption of broiler meat is rising rapidly worldwide $[1,2]$. Of all terrestrial meat-producing animals, broilers probably have the highest relative daily weight gain and the lowest feed conversion. Therefore, broiler meat is considered to be a relatively sustainable source of animal protein [3]. Unfortunately, disturbances of intestinal tract function are common in broilers, which can hamper their feed conversion due to inefficient digestion and absorption of nutrients [4]. These disturbances are associated with necrotic enteritis, coccidiosis $[5,6]$ and a range of ill-defined enteric syndromes of unclear etiology, sometimes classified under the common denominator of "dysbiosis". They constitute the major challenge to the broiler production today.

\footnotetext{
*Correspondence: Filip.VanImmerseel@UGent.be

${ }^{1}$ Department of Pathology, Bacteriology and Avian Diseases,

Faculty of Veterinary Medicine, Ghent University, Salisburylaan 133,

9820 Merelbeke, Belgium

Full list of author information is available at the end of the article
}

The intestinal mucosa is responsible for absorption of nutrients. To maintain a good intestinal barrier function, an optimal balance between the mucus layer, the intestinal epithelium and the microbiota is crucial [7]. A single layer of columnar epithelial cells which are connected by tight junctions is a crucial component of the intestinal barrier. It acts as a first protection against invasion of potentially harmful microorganisms, antigens and toxins from the intestinal lumen $[8,9]$. Reduced tight junction integrity and epithelial damage can thus result in a 'leaky gut' and are likely the main drivers for gut wall morphology changes, inflammation, systemic infection and malabsorption [10,11]. Poor gut health in broilers has indeed been associated with intestinal villus shortening [12], immune cell infiltration in the mucosal wall [13], and systemic spread of bacteria to organs, as is the case in bacterial chondronecrosis with osteomyelitis in broilers [14]. The importance of intestinal health in broilers is illustrated by the observation that more than $50 \%$ of the therapeutic use of antibiotics in broilers in the European Union, is to control intestinal pathologies [15]. 
Therapeutic usage of antibiotics may be the sole viable solution in flocks with severe advanced intestinal health problems.

Alternative, non-antibiotic, solutions for maintaining intestinal health include diet optimization and the use of feed additives, such as probiotics, acidifiers and essential oils [16]. The use of these products as preventive or curative tool requires early detection of intestinal health problems in broilers. Unfortunately, for the early stages of intestinal health defects, clinical indications are lacking. For measurement of the subclinical level of dysbiosis, field veterinarians and researchers use a macroscopic scoring system [17] but this is labor-intensive and requires necropsy of the animals. These observations have fueled intensive research hunting for specific biomarkers of intestinal health, or deficiency thereof [18]. In humans, fecal markers such as calprotectin, a stable protein that is contained in secretory granules of neutrophils, are used to evaluate inflammation in case of severe gut disease $[19,20]$. In poultry, several attempts have been reported to identify suitable biomarkers for gut barrier failure, mostly in serum samples, either with or without an experimental intervention [10,21]. Most of these studies have analyzed specific candidate biomarkers, often homologues of molecules considered to be of value in detection of gut health problems in mammals. Until now, few seem to be ready for practical use in the field. Recently, ovotransferrin has been proposed as fecal biomarker for intestinal leakage caused by coccidiosis and necrotic enteritis in broilers [22].

A first step in the development of a reliable, rapid and non-invasive diagnostic assay to monitor gut health is the identification of suitable biomarkers. Biomarkers for intestinal health defects, that can be used on fresh fecal droppings or litter, would be a huge asset. The aim of this study, therefore, was to identify intestinal biomarkers for evaluation of intestinal health using a gut damage model in broilers. Preferably the biomarkers should be of peptide or protein nature, as this may ultimately allow detection by a simple immunoassay. Therefore, an unbiased proteomic approach was used.

\section{Materials and methods}

\section{Animal trials and sample collection}

The experiment was approved by the Ethical Committee of Poulpharm BVBA, Izegem, Belgium (bacterial enteritis trial; P1606-FP) with approval number LA1400564. The animal experiment was carried out in accordance with approved guidelines.

\section{Bacterial inoculum}

A bacterial inoculum consisting of a mixture of Escherichia coli (G.78.71), Enterococcus faecalis (G.78.62),
Lactobacillus salivarius (LMG22873), Lactobacillus crispatus (LMG49479), Clostridium perfringens (netB-) (D.39.61) and Ruminococcus gnavus (LMG27713) was prepared. Luria-Bertani broth (LB, Oxoid) was used for growing E. coli. E. faecalis and C. perfringens were grown in Brain Heart Infusion (BHI, Sigma, Belgium) broth. Man-Rogosa-Sharpe (MRS, Oxoid) medium was used for the growth of $L$. crispatus and $L$. salivarius. For the growth of $R$. gnavus, anaerobic M2GSC medium (pH 6) as described by Miyazaki et al. [23] was used but with $15 \%$ clarified rumen fluid instead of $30 \%$ and addition of $1 \mathrm{mg} / \mathrm{mL}$ cysteine $\mathrm{HCl}$ and $4 \mathrm{mg} / \mathrm{mL} \mathrm{NaHCO}_{3}$ after autoclaving. E. coli and $E$. faecalis were cultured in aerobic conditions at $37^{\circ} \mathrm{C}$. Lactobacillus spp. were cultured in an micro aerobic $\left(5 \% \mathrm{O}_{2}\right)$ incubator, $C$. perfringens and $R$. gnavus were cultured in an anaerobic chamber (gas mixture $80 \% \mathrm{~N}_{2}, 10 \% \mathrm{CO}_{2}$ and $10 \% \mathrm{H}_{2}$, GP[concept], Jacomex, France) at $37{ }^{\circ} \mathrm{C}$. The bacterial cells were collected by centrifugation (10 $000 \mathrm{rpm}, 10 \mathrm{~min}, 20{ }^{\circ} \mathrm{C}$ ) and each pellet was resuspended in anaerobic phosphate buffered saline (PBS, $1 \mathrm{mg} / \mathrm{mL}$ cysteine $\mathrm{HCl}, \mathrm{pH}$ 6) whereby the number of colony-forming units $(\mathrm{CFU}) / \mathrm{mL}$ was determined by counting the colonies on the plates of a tenfold serial dilution of the suspension before mixing together. Table 1 is showing the final concentration of each strain after mixing the original cultures.

\section{Study design}

A total of 360 day-old broiler chicks (Ross 308) was obtained from a local hatchery and housed in floor pens on wood shavings. Throughout the study, feed and drinking water were provided ad libitum. The broilers were randomly assigned to two groups, a control and challenge group (9 pens per treatment and 20 birds per pen). All animals were fed a commercial feed till day 12 when the feed was switched to a wheat (57.5\%) based diet supplemented with $5 \%$ rye (Table 2 ). From day 12 to 18 , all animals from the challenge group received $10 \mathrm{mg}$ florfenicol and $10 \mathrm{mg}$ enrofloxacin per $\mathrm{kg}$ body weight via the drinking water daily. After the antibiotic treatment, $1 \mathrm{~mL}$ of the bacterial cocktail consisting of Escherichia coli (G.78.71), Enterococcus faecalis (G.78.62), Lactobacillus salivarius (LMG22873), Lactobacillus crispatus (LMG49479), Clostridium perfringens (netB-) (D.39.61) and Ruminococcus gnavus (LMG27713) was given daily by oral gavage from day 19 till 21 . On day 20, the animals were administered $1 \mathrm{~mL}$ of a coccidial suspension consisting of 60000 oocysts of Eimeria acervulina and 30000 oocysts of Eimeria maxima via oral gavage. At day 26, 3 birds per pen were euthanized. The duodenal loop was sampled for histological examination and ileal and colonic content was collected and stored at $-20{ }^{\circ} \mathrm{C}$ until required for protein extraction. At day 12 and day 
Table 1 Composition of the bacterial cocktail for oral inoculation

\begin{tabular}{llll}
\hline Bacterial strain & Day 19 (CFU/mL) & Day 20 (CFU/mL) & Day 21 (CFU/mL) \\
\hline E. coli & $2.11 \times 10^{9}$ & $1.22 \times 10^{9}$ & $2.28 \times 10^{9}$ \\
Enterococcus faecalis & $3.44 \times 10^{9}$ & $2.28 \times 10^{10}$ & $3.56 \times 10^{9}$ \\
Lactobacillus salivarius & $4.78 \times 10^{7}$ & $1.16 \times 10^{7}$ & $2.39 \times 10^{7}$ \\
Lactobacillus crispatus & $1.89 \times 10^{9}$ & $7.78 \times 10^{7}$ & $7.22 \times 10^{6}$ \\
Clostridium perfringens & $1 \times 10^{7}$ & $1.06 \times 10^{7}$ & $2.78 \times 10^{8}$ \\
Ruminococcus gnavus & $2.89 \times 10^{8}$ & $2.78 \times 10^{8}$ & $3.17 \times 10^{8}$ \\
\hline
\end{tabular}

Broilers in the challenge group were orally inoculated with $1 \mathrm{~mL}$ of a bacterial cocktail consisting of Escherichia coli, Enterococcus faecalis, Lactobacillus salivarius, Lactobacillus crispatus, Clostridium perfringens (netB-) and Ruminococcus gnavus on day 19, 20 and 21, with number of colony-forming units (CFU) per strain as indicated in the table.

Table 2 Composition and nutrient content of the wheat/rye based broiler diet

\begin{tabular}{|c|c|c|c|c|c|}
\hline Feedstuff & $\begin{array}{l}\text { Starter } \\
\%\end{array}$ & $\begin{array}{l}\text { Grower } \\
\%\end{array}$ & $\begin{array}{l}\text { Calculated nutrient } \\
\text { composition }\end{array}$ & $\begin{array}{l}\text { Starter } \\
\%\end{array}$ & $\begin{array}{l}\text { Grower } \\
\%\end{array}$ \\
\hline Wheat & 55.13 & 57.87 & Dry matter & 88.45 & 88.38 \\
\hline Rye & 0.00 & 5.00 & Ash & 5.11 & 4.79 \\
\hline Soy meal, crude fiber content $<50$ & 22.86 & 22.86 & Crude protein & 20.85 & 18.98 \\
\hline Full fat soy beans & 7.50 & 2.50 & Crude fat & 10.83 & 9.90 \\
\hline Rapeseed meal <380 & 2.74 & 0.00 & Crude fiber & 2.93 & 2.49 \\
\hline Animal fat & 7.20 & 7.20 & Carbohydrates & 48.46 & 51.95 \\
\hline Soybean oil & 1.00 & 1.00 & Starch & 34.62 & 38.46 \\
\hline Premix (maize) & 0.50 & 0.50 & Sugars & 4.77 & 4.53 \\
\hline Lime fine & 1.11 & 1.11 & NDF & 10.52 & 9.93 \\
\hline Monocalcium phosphate & 0.83 & 0.83 & ADF & 4.18 & 3.52 \\
\hline Salt & 0.18 & 0.18 & Calcium & 0.69 & 0.66 \\
\hline $\mathrm{NaHCO}_{3}$ & 0.25 & 0.25 & Phosphorus, total & 0.57 & 0.54 \\
\hline L-Lysine $\mathrm{HCl}$ & 0.30 & 0.30 & Calcium/dP poultry & 0.22 & 0.22 \\
\hline DL-Methionine & 0.30 & 0.30 & Magnesium & 0.16 & 0.14 \\
\hline \multirow[t]{5}{*}{ L-Threonine } & 0.10 & 0.10 & Potassium & 0.88 & 0.79 \\
\hline & & & Sodium & 0.15 & 0.15 \\
\hline & & & Chloride & 0.20 & 0.20 \\
\hline & & & Base-excess (mEq/kg) & 23.39 & 20.97 \\
\hline & & & Linolic acid & 2.38 & 1.92 \\
\hline
\end{tabular}

Starter diet, a commercial feed, administered to all broilers till day 11 . From day 12 to 26 , all animals received a grower diet, wheat (57.5\%) supplemented with rye (5\%).

26, birds and feed were weighed in order to determine daily weight gain (DWG), daily feed intake (DFI) and feed conversion ratio (FCR) (Table 3). A schematic presentation of the protocol is shown in Figure 1.

\section{Macroscopic gut wall appearance scoring system}

The macroscopic appearance of the gut was evaluated using a previously described scoring system [17], in which 10 parameters were evaluated and assigned 0 (absent) or 1 (present), resulting in a total score between 0 and 10. A total score of 0 to 2 represents a normal appearance of the intestinal tract while score
10 points to severe deviations from the normal appearance. The parameters are (1) "ballooning" of the gut; (2) inflammation, cranial to Meckel's diverticulum; (3) macroscopically visible and tangible fragile small intestine cranial to Meckel's diverticulum; (4) loss of tonus at longitudinal cutting of the intestine cranial to the Meckel's diverticulum within $3 \mathrm{~s}$ after incision; (5) abnormal appearance of the intestinal content (excess mucus, orange content, gas) cranial to Meckel's diverticulum; $(6,7,8,9)$ are identical to $(2,3,4,5)$ but caudal to Meckel's diverticulum and (10) presence of undigested particles in the colon. 
Table 3 Mean \pm standard deviation of performance parameters

\begin{tabular}{llccr}
\hline Time period & Parameters & $\begin{array}{l}\text { Control } \\
\text { Mean } \pm \text { SD }\end{array}$ & $\begin{array}{c}\text { Challenge } \\
\text { Mean } \pm \text { SD }\end{array}$ & $p$-value \\
\hline D1-D12 & BW D12 (g) & $290 \pm 13$ & $295 \pm 11$ & 0.485 \\
& DWG (g) & $19.6 \pm 1$ & $20.2 \pm 1$ & 0.342 \\
& DFI (g) & $24 \pm 1$ & $25 \pm 1$ & 0.614 \\
& FCR & $1.25 \pm 0.06$ & $1.23 \pm 0.05$ & 0.321 \\
D12-D26 & BW D26 (g) & $1375 \pm 58$ & $1187 \pm 46$ & $<0.001$ \\
& DWG (g) & $78 \pm 4$ & $64 \pm 4$ & $<0.001$ \\
& DFI (g) & $116 \pm 6$ & $108 \pm 7$ & 0.014 \\
& FCR & $1.50 \pm 0.07$ & $1.69 \pm 0.18$ & 0.004 \\
\hline
\end{tabular}

Body weight (BW), daily weight gain (DWG), daily feed intake (DFI) and feed conversion ratio (FCR) was measured at day 12 and day 26 for the control and challenge group. Significant differences $(p<0.05)$ are shown in italic.

A coccidiosis scoring was performed as described by Johnson and Reid [24]. The animals were given a score for typical lesions associated with E. acervulina, E. maxima and E. tenella. For each species, a score was given between 0 (absent) and 4 (severe). A total coccidiosis score was calculated as the sum of the three individual Eimeria species scores.

\section{Morphological parameters}

The duodenal loops were fixated in $4 \%$ formaldehyde for $24 \mathrm{~h}$, dehydrated in xylene and embedded in paraffin. Sections of $4 \mu \mathrm{m}$ were cut using a microtome (HM360, Thermo Scientific, Waltham, MA, USA) and processed as described by De Maesschalck et al. [25]. After staining with haematoxylin and eosin, morphological parameters were assessed using standard light microscopy. Villus length, measured from the crypt-villus junction to the villus tip, and crypt depth, measured from the junction to the base, in the duodenum were determined by random measurement of 12 villi per section using a Leica DM LB2 microscope equipped with a camera and a computer based image analysis program, LAS V4.1 (Leica Application Suite V4, Wetzlar, Germany). The average villus length, crypt depth and villus-to-crypt ratio was determined for 3 animals per pen for 9 pens per treatment.

\section{Immunohistochemical examination}

Antigen retrieval was performed on $4 \mu \mathrm{m}$ duodenal sections with a pressure cooker in citrate buffer $(10 \mathrm{mM}$, pH 6). Slides were rinsed with washing buffer (Dako kit, K4011, Glostrup, Denmark) and blocked with peroxidase reagent (Dako, S2023) for $5 \mathrm{~min}$. Slides were rinsed with distilled water and Dako washing buffer before incubation with anti-CD $\mathrm{CD}_{3}$ primary antibodies (Dako $\mathrm{CD}_{3}$, A0452) for $30 \mathrm{~min}$ at room temperature diluted 1:100 in antibody diluent (Dako, S3022). After rinsing again with washing buffer, slides were incubated with labelled polymer-HRP anti-rabbit (Envision ${ }^{+}$System-HRP, K4011) for $30 \mathrm{~min}$ at room temperature. Before adding di-amino-benzidine $\left(\mathrm{DAB}^{+}\right)$substrate and $\mathrm{DAB}^{+}$chromogen (Dako kit, K4011) for 5 min, slides were rinsed 2 times with washing buffer. To stop the staining, the slides were rinsed with distilled water, dehydrated using the Shandon Varistain-Gemini Automated Slide Stainer

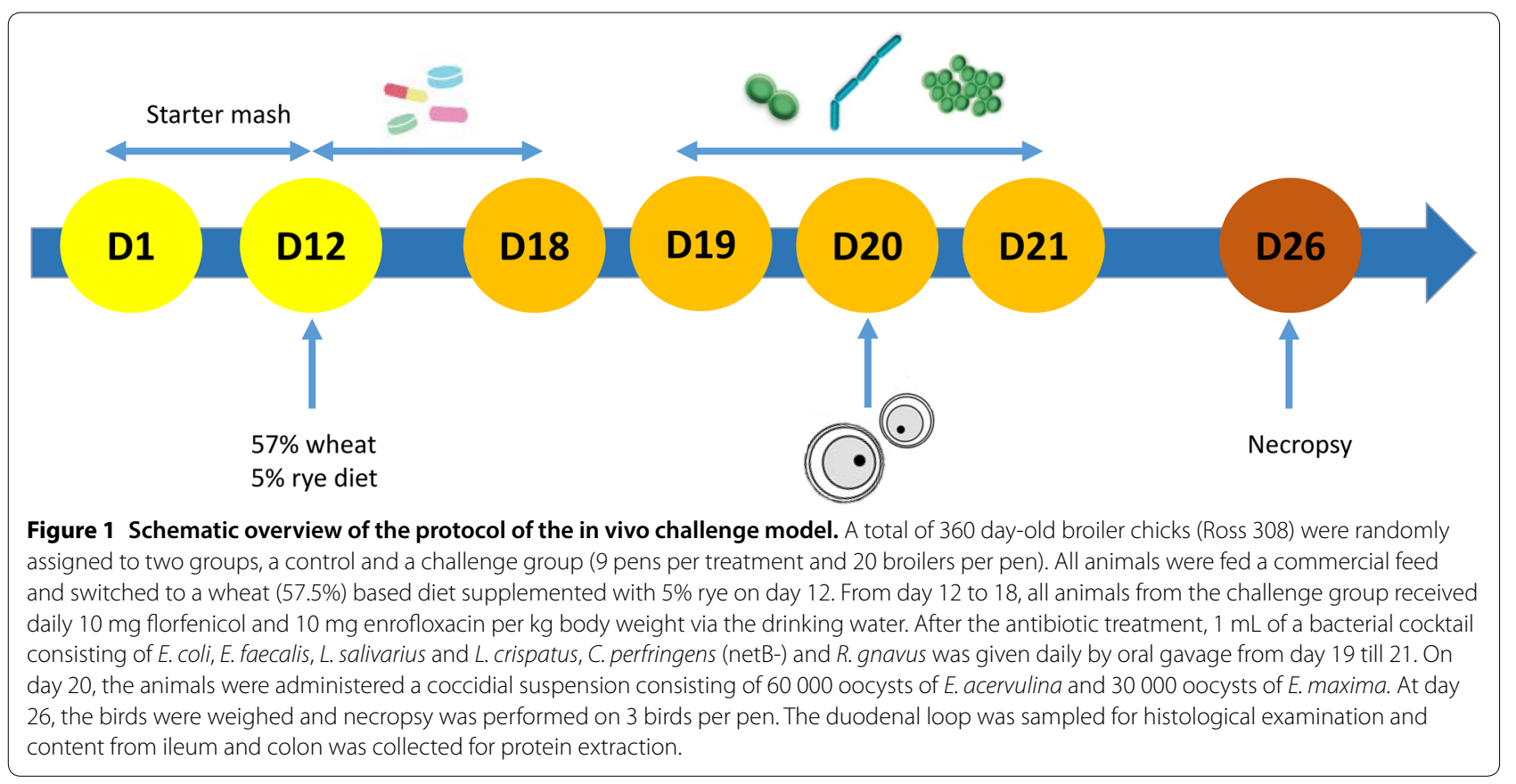


and counterstained with hematoxylin for $10 \mathrm{~s}$. The slides were analyzed with a Leica DM LB2 microscope and a computer based image analysis program LAS V4.1 (Leica Application Suite V4, Germany) to measure $\mathrm{CD}_{3}$ positive cells in a total area of $3.5 \pm 0.5 \mathrm{~mm}^{2}$ which represents the area of approximately 10 to 12 villi.

\section{Discovery proteomics \\ Sample preparation}

Five hundred mg content of each colon and ileum sample, from 1 bird per pen for 9 pens per treatment, was solubilized in $10 \mathrm{~mL}$ extraction buffer $(2 \mathrm{M}$ urea, $50 \mathrm{mM}$ ammonium bicarbonate). After homogenizing by vortexing and centrifugation $\left(20000 \times g, 15 \mathrm{~min}, 4{ }^{\circ} \mathrm{C}\right)$, the supernatant was filtered through a $0.22 \mu \mathrm{m}$ filter (Merck, Darmstadt, Germany) directly in a Vivaspin 20 with a $5 \mathrm{kDa}$ MWCO filter (Sartorius, Göttingen, Germany) and centrifuged for $1 \mathrm{~h}$ at $4000 \times g$. The filter was washed 3 times with $1 \mathrm{~mL}$ extraction buffer followed by centrifugation $\left(4000 \times g, 10 \mathrm{~min}, 4^{\circ} \mathrm{C}\right)$. The samples were washed 3 times with $1 \mathrm{~mL} 500 \mathrm{mM}$ triethylammonium bicarbonate buffer (TEABC, Sigma, Belgium) to remove the urea. Subsequently, the samples were concentrated to a volume of $\pm 500 \mu \mathrm{L}$. To determine the protein concentration, a Bradford assay was performed where OD was measured at $595 \mathrm{~nm}$. Samples were diluted with TEABC buffer to obtain $50 \mu \mathrm{g}$ of protein which was then reduced with dithiothreitol (DTT) from a $10 \mathrm{mM}$ stock to a final concentration of $1 \mathrm{mM}$ and incubated at $60{ }^{\circ} \mathrm{C}$ for $30 \mathrm{~min}$, followed by alkylation for $10 \mathrm{~min}$ at room temperature with $200 \mathrm{mM}$ methyl methanethiosulfonate (MMTS) to achieve a final concentration of $10 \mathrm{mM}$ MMTS. Hereafter, $10 \mathrm{mM}$ calcium chloride and $100 \%$ acetonitrile were added to a final concentration of $1 \mathrm{mM}$ and $5 \%$ respectively. Finally, trypsin of a $1 \mu \mathrm{g} / \mu \mathrm{L}$ stock was added in a 1:20 (trypsin:protein) ratio for overnight digestion at $37{ }^{\circ} \mathrm{C}$. The samples were vacuum dried and analyzed with high performance liquid chromatography-mass spectrometry (HPLC-MS).

\section{HPLC-MS}

Peptides were dissolved in $0.1 \%$ formic acid in HPLCgrade water (buffer A) to a final concentration of $1 \mu \mathrm{g} /$ $\mu \mathrm{L} .100 \mathrm{fmol}$ of mass prep digestion standard 2 (MPDS 2) was spiked into each sample. Data Dependent Acquisition MS analysis was performed on a TripleTOF 5600 (Sciex, Darmstadt, Germany) fitted with a DuoSpray ion source in positive ion mode, coupled to an Eksigent NanoLC 400 HPLC system (Sciex). Peptides were separated on a microLC YMC Triart C18 column (id $300 \mu \mathrm{m}$, length $15 \mathrm{~cm}$, particle size $3 \mu \mathrm{m}$ ) at a flow rate of $5 \mu \mathrm{L} /$ min by means of trap-elute injection (YMC Triart C18 guard column, id $500 \mu \mathrm{m}$, length $5 \mathrm{~mm}$, particle size
$3 \mu \mathrm{m})$. Elution was performed using a gradient of $4-40 \%$ buffer B $(0.1 \%$ formic acid, $5 \%$ DMSO in $80 \% \mathrm{ACN})$ over $90 \mathrm{~min}$. Ion source parameters were set to $5.5 \mathrm{kV}$ for the ion spray voltage, $30 \mathrm{psi}$ for the curtain gas, $13 \mathrm{psi}$ for the nebulizer gas and $80^{\circ} \mathrm{C}$ as temperature. For DDA, a $2.25 \mathrm{~s}$ instrument cycle was repeated in high sensitivity mode throughout the whole gradient, consisting of a full scan MS spectrum $(300-1250 \mathrm{~m} / \mathrm{z})$ with an accumulation time of $0.2 \mathrm{~s}$, followed by $20 \mathrm{MS} / \mathrm{MS}$ experiments $(50-1800 \mathrm{~m} / \mathrm{z})$ with $0.2 \mathrm{~s}$ accumulation time each, on MS precursors with charge state 2 to $5+$ exceeding a 500 cps threshold. Rolling collision energy was used as suggested by the manufacturer and former target ions were excluded for $10 \mathrm{~s}$.

\section{Database searching}

The ".wiff files generated during LC-MS/MS analysis were imported into the Progenesis QI for Proteomics software (non-linear dynamics). The different samples were aligned based on retention time and $\mathrm{m} / \mathrm{z}$ of reoccurring features to enable relative quantification. After subsequent peak picking, a merged ".mgf file was exported from the software and searched for identifications with MASCOT Daemon (Matrix Science, version 2.5.1) against a chicken database (reviewed protein database downloaded from Swissprot, January 2016) supplemented with the cRAP database (laboratory proteins and dust/contact proteins) and the internal standard. Maximum peptide mass tolerance and fragment mass tolerance were set to $10 \mathrm{ppm}$ and $0.1 \mathrm{Da}$ respectively. Additionally, methylthio on cysteine was set as a fixed modification and deamidation of asparagine and/or glutamine and oxidation of methionine were set as variable modifications. Enzyme specificity was set to trypsin with a maximum of one missed cleavage. The identifications were exported from MASCOT Daemon with a $1 \%$ false discovery rate ("${ }^{*} \mathrm{xml}$ format) and imported into Progenesis QI for Proteomics.

\section{Statistical analysis}

Statistical analysis of performance parameters, macroscopic scoring, intestinal morphology and immunohistochemistry was performed using Graphpad Prism (v.5, San Diego, USA). Statistical differences in macroscopic gut appearance and coccidiosis scores were determined using the Chi-square test. For the other parameters, pen (total of 3 birds per pen) was taken as experimental unit. To evaluate whether the data were normally distributed, a Kolmogorov-Smirnov test was performed. In case of a normal distribution, comparison between the control and challenge group was performed with an independent samples t-test. Otherwise, the non-parametric MannWhitney test was performed. Progenesis (v4.1) was used 

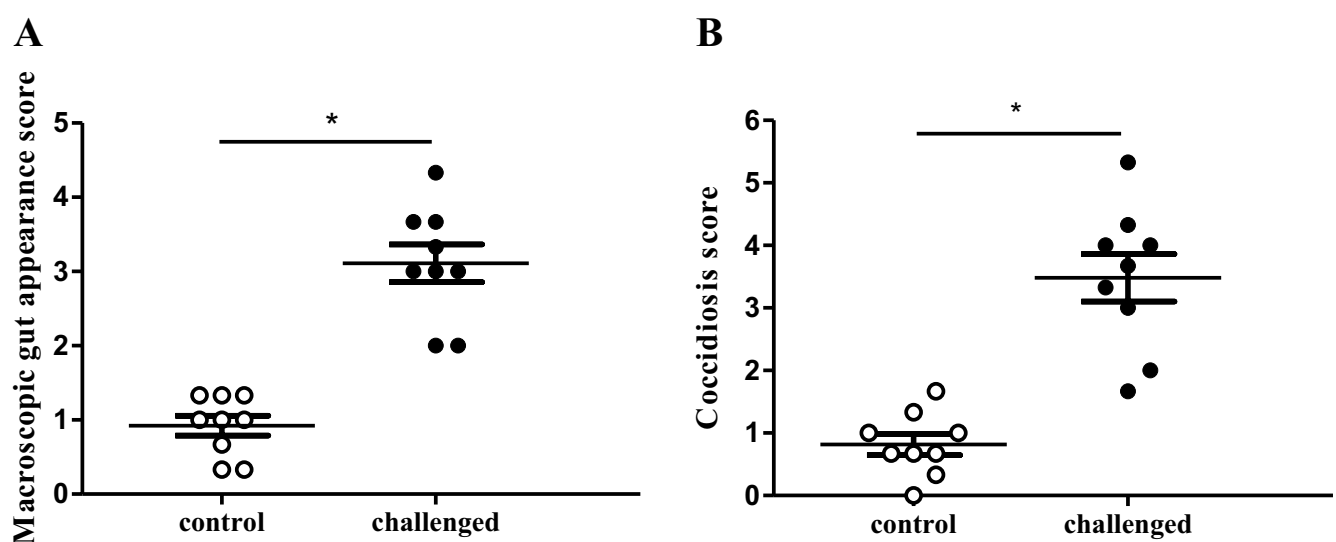

Figure 2 Macroscopic scoring parameters of intestine from broilers derived from the in vivo gut damage trial. Each dot represents the average score of 3 birds per pen with a total of 9 pens for control (white; $n=27$ ) and challenged (black; $n=27$ ) birds. A Macroscopic gut appearance score was determined by scoring of 10 parameters on assessment of absence (0) or presence (1) resulting in a total score between 0 and 10. B Coccidiosis score was determined by the sum of the individual species scores, 0 if absent to 4 if severe, for lesions caused by Eimeria (E.) acervulina, E. maxima and E. tenella. Asterisk denotes statistical significance of $p<0.0001$ between control and challenged animals.

for analysis of the proteomics data. Overall, a $p$-value of $\leq 0.05$ was considered statistically significant.

\section{Results}

\section{Performance parameters}

Body weight (BW), daily weight gain (DWG), daily feed intake (DFI) and feed conversion ratio (FCR) were measured at day 12 and 26. At day 26, challenged birds had a significant lower BW, DWG and DFI whereas FCR was increased $(p<0.05)$ (Table 3$)$.

\section{Macroscopic scoring}

The scores for macroscopic gut wall appearance $(3.11 \pm 0.76$ vs $0.92 \pm 0.4)$ and coccidiosis $(3.48 \pm 1.14$ vs $0.82 \pm 0.5)$ were higher in the challenge group compared to the control group respectively $(p<0.0001)$ (Figure 2$)$.

\section{Intestinal morphology and immunohistochemistry}

Significantly shorter villi $(1370 \pm 158.7 \mu \mathrm{m} \quad$ vs $2036 \pm 134.6 \mu \mathrm{m})$, deeper crypts $(365.7 \pm 31.4 \mu \mathrm{m}$ vs $190.1 \pm 15.4 \mu \mathrm{m})$, a lower villus-to-crypt ratio $(3.85 \pm 0.63$ vs $11.03 \pm 1.03)$ and higher infiltration of $\mathrm{CD}_{3}{ }^{+}$cells $(13.71 \pm 2.22$ area\% vs $7.86 \pm 0.77$ area\% $)(p<0.0001)$ were detected in the duodenal sections of animals from the challenge group as compared to the control group respectively (Figure 3).

\section{Discovery proteomics}

Using MASCOT Daemon (Matrix Science, version 2.5.1) against a chicken database (reviewed protein database downloaded from Swissprot, January 2016) supplemented with the cRAP database (laboratory proteins and dust/contact proteins), 157 and 181 proteins were identified for colon and ileum respectively. In broilers from the challenge group, the following proteins showed a significantly higher abundance compared to control animals in colonic content $(p<0.05)$ : alphaactinin-4 (ACTN4), annexin A5 (ANXA5), apolipoprotein A-1 (APOA1), fibronectin (FINC), hemoglobin subunit beta (HBB), myeloid protein 1 (MIM1), nucleophosmin (NPM), ovoinhibitor (IOV7) and transthyretin (TTR). Both in colonic and ileal content, superoxide dismutase $[\mathrm{Cu}-\mathrm{Zn}]$ (SOD) showed a decreased abundance compared to control animals $(p<0.05)$. Angiotensinconverting enzyme (ACE), mitochondrial aspartate aminotransferase (AATM), cathepsin D (CATD), Ig lambda chain $C$ region (LAC), Ig lambda chain $\mathrm{V}-1$ region (LV1), TTR and WD repeat-containing protein 1 (WDR1) showed a lower abundance in challenged birds $(p<0.05)$ in ileal samples. Following proteins were more abundant in challenged birds $(p<0.05)$ : APOA1, histone H2A-IV (H2A4) and retinol-binding protein 4 (RET4) (Figure 4, Tables 4 and 5).

\section{Discussion}

Intestinal inflammation models that do not induce clinical signs, but affect zootechnical parameters by using triggers that are common under field conditions are the models of choice to identify biomarkers for intestinal health. Coccidiosis is the most common intestinal disease in broilers, and coccidiosis lesions caused by E. maxima and $E$. acervulina are frequently observed in broilers [26, 27]. The diet shift, antibiotic treatment, and subsequent oral administration of a mix of bacterial opportunistic pathogens and commensals, was performed to mimic a decrease in bacterial diversity and to induce dysbiosis. 

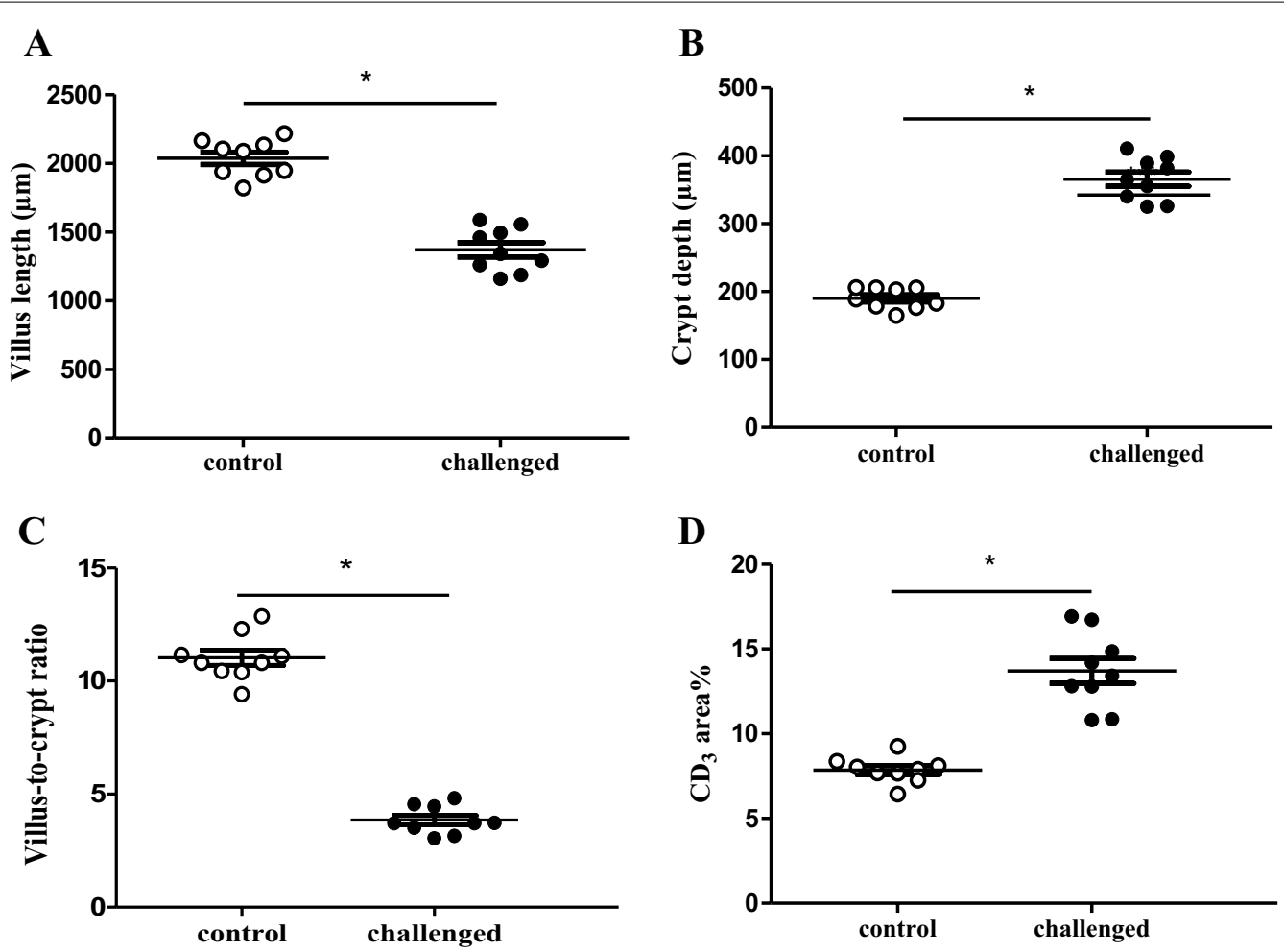

Figure 3 Histological parameters in duodenal sections from birds derived from the in vivo gut damage trial. 12 villi were randomly selected and measured per section and per animal using Leica DM LB2 microscope and a computer based image analysis program, LAS V4.1. Each dot represents the mean of 3 birds per pen with a total of 9 pens for control (white; $n=27$ ) and challenged (black; $n=27$ ) birds. A Villus length was measured from the crypt-villus junction to villus tip. B Crypt depth was measured from the junction to the base. C Villus-to-crypt ratio. $\mathbf{D}$ T-lymphocyte infiltration $\left(\mathrm{CD}_{3}\right.$ area\%) was measured for a total area of $3.5 \pm 0.5 \mathrm{~mm}^{2}$. Asterisk denotes statistical significance of $p<0.0001$ between control and challenge group.

Feed changes to more non-starch polysaccharide (NSP) containing cereals (e.g. rye) have been shown to affect microbial composition and animal performance [10, 28]. E. coli and R. gnavus are enriched in human patients with inflammatory bowel disease (IBD) often characterized with increased disease activity [29]. Also excess accumulation of lactic acid bacteria has been described to form part of a dysbiotic microbiota in humans, although these can also be beneficial, but this seems to be species and even strain dependent [30]. In addition, intestinal overgrowth of $C$. perfringens, even netB negative strains which are considered to be non-pathogenic for poultry, in combination with other predisposing factors such as Eimeria and indigestible NSPs are considered to induce small intestinal microbial perturbations [31]. The triggers used in the current model are thus biologically relevant, in contrast to chemical triggers of inflammation, such as dextran sulphate sodium (DSS), lipopolysaccharide (LPS) or feed restriction models that have been used in other studies in broilers [21,32].

The model used in the current study led to shorter villi, deeper crypts and more infiltration of $\mathrm{CD}_{3}{ }^{+} \mathrm{T}$-cells, in association with performance losses, but without clinical symptoms. These findings confirm that the in vivo model can be used to evaluate gut damage and to identify gut health biomarkers. Detection of protein biomarkers was performed in ileal and colonic content. The latter was chosen as a proxy for fecal material, to exclude issues that are related to protein breakdown in litter and lack of homogeneity of mixed fecal material, what are likely main problems in practical development of protein quantification methods in the field.

In the current study, biomarker candidates were selected based on significant differences $(p<0.05)$ in protein abundance between control and challenged birds in ileal and/or colonic content. The normalized protein abundance mostly was higher in the ileal content compared to the colonic content samples (Figure 4), which indicates that the used model induces proximal intestinal damage following release of host proteins in ileal content, and degradation of these proteins during passage further down the intestinal tract occurs.

The proteins that were identified as more abundant in challenged animals compared to control animals were 


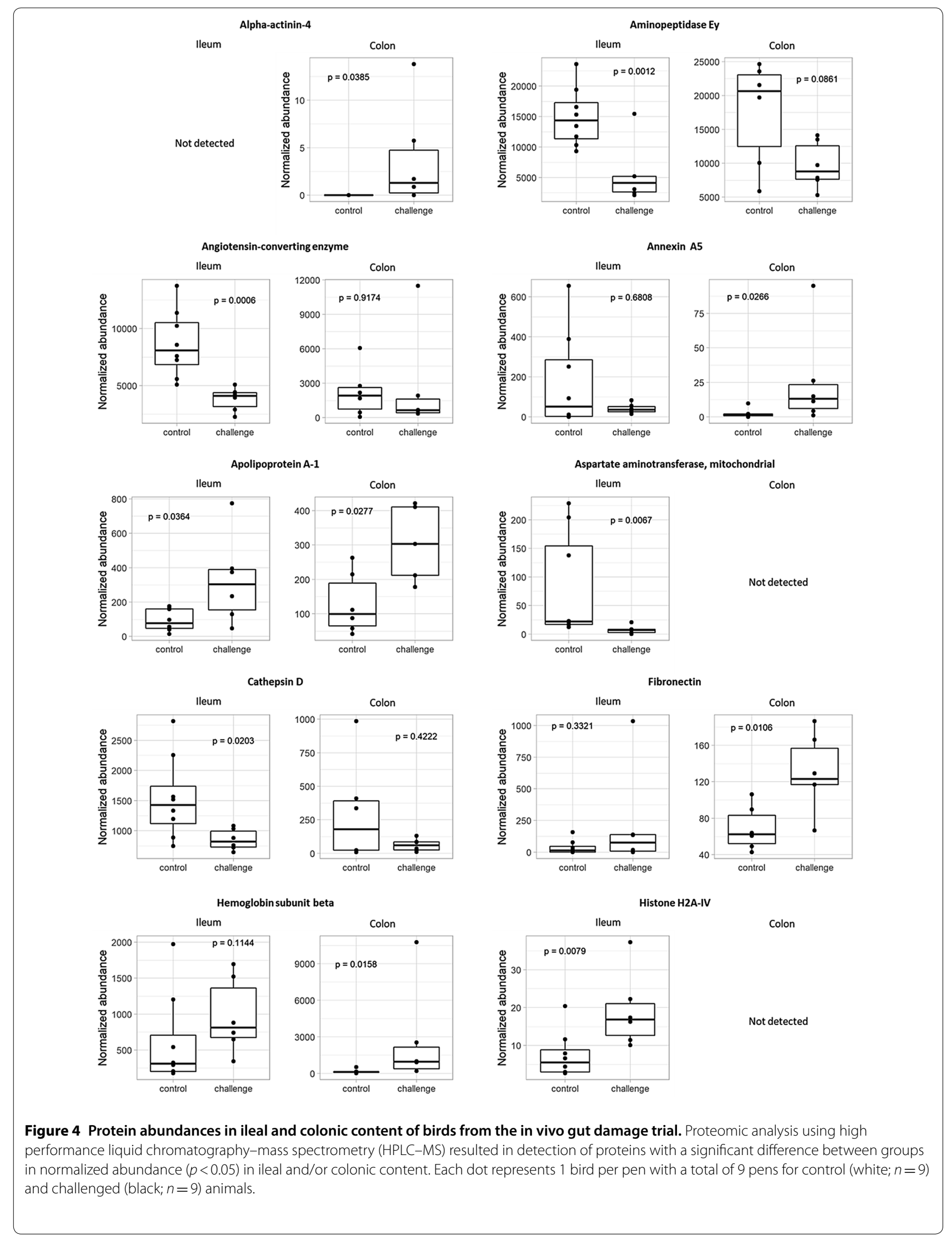



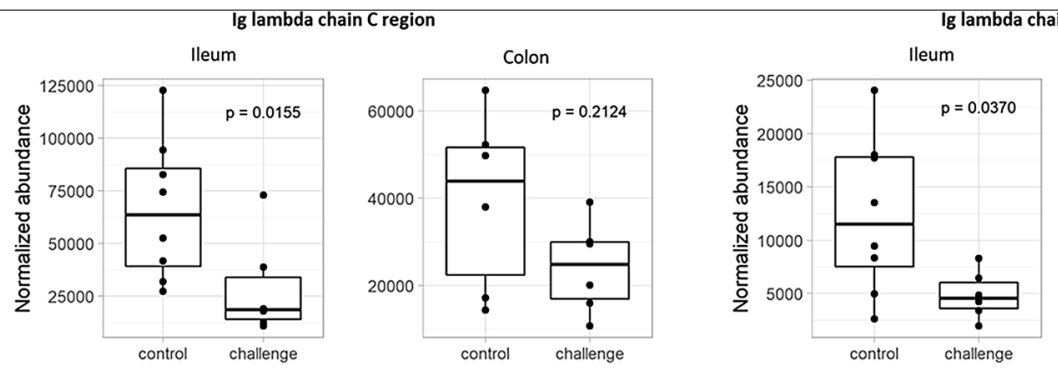

Colon
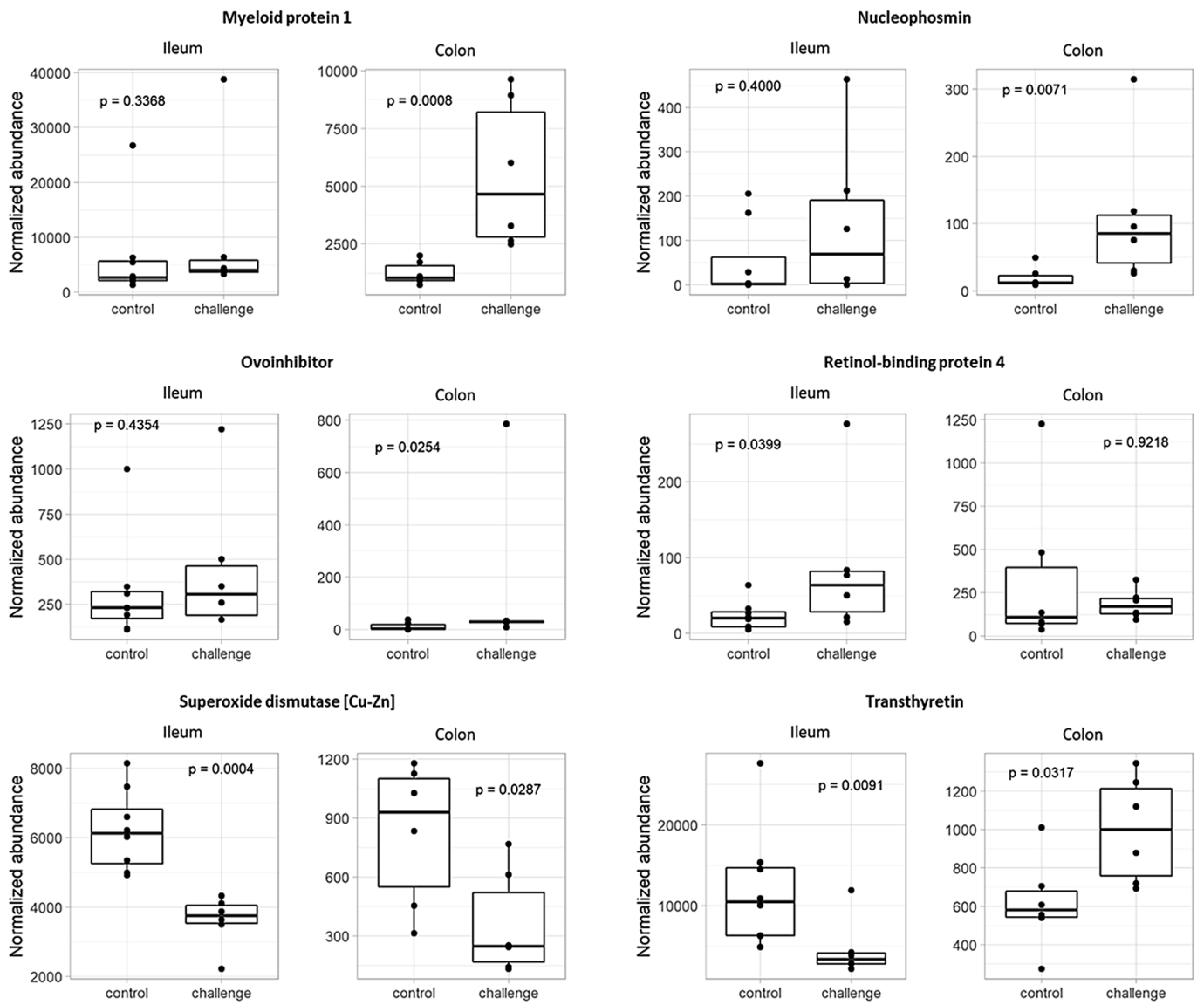

Not detected

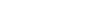


associated with inflammation, serum leakage and tissue destruction. A clear inflammation marker that was identified as more abundant in the colon of challenged animals was myeloid protein 1 (MIM1) and was the most discriminating protein detected between control and challenged birds (Table 4). Myeloid protein 1 is expressed in myeloid cells and is present in large amounts in secretory granules of heterophilic granulocytes [33]. Amongst other leukocytes, activated heterophils can infiltrate the mucosa, transmigrate through the intestinal epithelium and degranulate in the intestinal lumen when an inflammatory trigger targets the epithelium [34, 35]. High fecal or intestinal content levels of MIM1 are thus specific for inflammatory intestinal disorders. In man, a neutrophil granule protein, calprotectin, is used in clinical practice to evaluate intestinal inflammation [36]. Fecal calprotectin levels reflect disease activity in IBD [37]. The MIM1 protein, and in extension all heterophil secretory granule proteins, may thus represent useful intestinal inflammation biomarkers.

Tissue damage markers are a second set of proteins that are more abundant in the intestinal lumen of challenged compared to control animals. Damage of the intestinal epithelial barrier, invasion by microorganisms or entry of antigens in the mucosal tissue below the epithelial layer leads to mucosal inflammation and subsequent tissue damage [36]. Due to the tissue damage or destruction, tissue specific proteins can be released and end up in intestinal content. One of these proteins is fibronectin (FINC). Fibronectin is a high molecular weight glycoprotein that is found in the basement membrane and extracellular matrix in the intestinal wall (insoluble form) and in plasma (soluble form) [38]. It has been shown that the expression of epithelial-derived fibronectin is highly upregulated in DSS-induced colitis models [39]. Fibronectin can potentiate cell attachment and wound healing through epithelial-matrix interactions and its expression is supposed to be vital for maintaining normal epithelial integrity as well as regulating epithelial response to injury during colitis [39]. Intestinal damage in our current study could thus have resulted in an increased expression of epithelial or fibroblast-derived fibronectin, release of matrix fibronectin or even leakage of plasma fibronectin, explaining the increased levels in the intestinal content of challenged animals.

Two nuclear proteins were identified as being more abundant in intestinal content of challenged animals, namely histone H2A-IV (H2A4) and nucleophosmin (NPM). H2A4 is a core component of nucleosomes that wraps and packages DNA into chromatin [40]. The high abundance in challenged animals may be explained by increased cell death. NPM is a phosphoprotein that initiates $\mathrm{p} 53$, a tumor suppressor gene which drives the cell to apoptosis [41]. Overexpression of NPM is associated with cell proliferation [42]. Parker et al. [43] states that cell proliferation within small intestinal crypts is the primary force that drives cell migration along the villus. Challenged broilers had longer crypts than the control animals which indicates more cell proliferation, likely in an attempt to repair lesions.

Epithelial damage has been shown to be associated with altered protein expression and distribution of intercellular connections, including tight junctions [44]. Alpha-actinin-4 (ACTN4), found to be more abundant in intestinal content in the challenge group as compared to the control group, was shown to be localized in the apical part of chicken intestinal epithelial cells

Table 4 Proteins of which the normalized abundance in colonic content was significantly different between control and challenged groups

\begin{tabular}{|c|c|c|c|c|}
\hline Accession number & Protein name & Abbreviation & $p$-value & Highest mean \\
\hline Q90734 & Alpha-actinin-4 & ACTN4 & 0.0385 & Challenge \\
\hline P17153 & Annexin A5 & ANXA5 & 0.0266 & Challenge \\
\hline P08250 & Apolipoprotein A-1 & APOA 1 & 0.0277 & Challenge \\
\hline P11722 & Fibronectin & FINC & 0.0106 & Challenge \\
\hline P02112 & Hemoglobin subunit beta & $\mathrm{HBB}$ & 0.0158 & Challenge \\
\hline P08940 & Myeloid protein 1 & MIM1 & 0.0008 & Challenge \\
\hline P16039 & Nucleophosmin & NPM & 0.0071 & Challenge \\
\hline P10184 & Ovoinhibitor & IOV7 & 0.0254 & Challenge \\
\hline P80566 & Superoxide dismutase [Cu-Zn] & SOD & 0.0287 & Control \\
\hline P27731 & Transthyretin & TTR & 0.0317 & Challenge \\
\hline
\end{tabular}

Proteomics using high performance liquid chromatography-mass spectrometry (HPLC-MS) was performed on colonic content of animals from the control ( $n=9$ ) and challenged $(n=9)$ group at day 26 . This resulted in 9 proteins with a significantly higher normalize abundance $(p<0.05)$ and 1 protein with a significantly lower normalized abundance $(p<0.05)$ in challenged birds. 
Table 5 Proteins of which the normalized abundance in ileal content was significantly different between control and challenged groups

\begin{tabular}{llllc}
\hline Accession number & Protein name & Abbreviation & H-value & Highest mean \\
\hline O57579 & Aminopeptidase Ey & AMPN & 0.0012 & Control \\
Q10751 & Angiotensin-Converting enzyme & ACE & 0.0006 & Control \\
P08250 & Apolipoprotein A-1 & APOA1 & 0.0364 & Challenge \\
P00508 & Aspartate aminotransferase, mitochondrial & AATM & 0.0067 & Control \\
Q05744 & Cathepsin D & CATD & 0.0203 & Control \\
P02263 & Histone H2A-IV & H2A4 & 0.0079 & Challenge \\
P20763 & Ig lambda chain C region & LAC & 0.0155 & Control \\
P04210 & Ig lambda chain V-1 region & LV1 & 0.0370 & Control \\
P41263 & Retinol-binding protein 4 & RET4 & 0.0399 & Challenge \\
P80566 & Superoxide dismutase [Cu-Zn] & SOD & 0.0004 & Control \\
P27731 & Transthyretin & TTR & 0.0091 & Control \\
O93277 & WD repeat-containing protein 1 & WDR1 & 0.0027 & Control \\
\hline
\end{tabular}

Proteomics using high performance liquid chromatography-mass spectrometry (HPLC-MS) was performed on ileal content of animals from the control ( $n=9$ ) and challenge $(n=9)$ group at day 26 . This resulted in 3 proteins with a significantly higher normalized abundance $(p<0.05)$ and 9 proteins with a significantly lower normalized abundance $(p<0.05)$ in challenged birds.

[45], more specifically as a component of the tight junction (zonula occludens) [46] and/or belt desmosomes (zonula adherens) [47]. Changes in gut permeability induced by enteric pathogens and/or parasites can also be the consequence of damage to these tight junctions [48]. Release of alpha-actinin-4 in the intestinal content of challenged animals might thus result from a higher expression and damaged tight junction and zonula adherens complexes.

Reduced tight junction integrity allows paracellular translocation of large molecules in both directions, thus loss of plasma proteins from the host into the intestinal lumen and undesirable foreign substances from the lumen into the blood. Multiple proteins found to be higher abundant in the intestinal content of challenged animals are hypothesized to leak from the serum to the intestinal content because of mucosal damage. In our current model, the dysbiosis and the coccidial infection might have resulted in production of acute-phase proteins (APPs) by the liver [49]. In mammalian species, APPs apolipoprotein A-1 (APOA1), transthyretin (TTR) and retinol-binding protein 4 (RET4) behave as negative APPs of which the concentration decreases in plasma during an acute phase response (APR). The exact behavior of the expression in the liver of chickens is unknown [50]. Apolipoprotein A-1 (APOA1) is the major protein fraction of high-density lipoprotein (HDL) particles in plasma [51]. However, in avian species, APOA1 could also be expressed in numerous tissues other than the liver, such as absorptive intestinal epithelial cells, so our data could imply intestinal epithelial cell loss [52, 53]. Transthyretin (TTR) is a highly conserved protein in animal species that is involved in transport of thyroid hormones and retinol bound to retinol-binding protein 4 (RET4) in the bloodstream [54]. Retinol (vitamin A) is known to be essential for differentiation and proliferation of epithelial cells [55]. Ovoinhibitor (IOV7) is a serine proteinase inhibitor that can reduce enzymatic digestion by trypsin and chymotrypsin [56]. The detection of hemoglobin subunit beta (HBB) in intestinal content indicates that the administered challenges induced gut leakage and likely also endothelial damage allowing red blood cell leakage from the blood to the lumen.

A final protein that was found to be more abundant in colonic content of challenged animals is annexin A5 (ANXA5). Both apoptotic and necrotic cells expose phosphatidylserine (PS), a major "eat-me" signal for phagocytes and for which ANXA5 binds with high affinity and specificity followed by initiation of an immune reaction [57]. Van Genderen [58] suggests that the presence of extracellular ANXA5 is a consequence of release of cytosolic content from dead cells into the surrounding environment.

Proteins that were identified as less abundant in challenged animals compared to control animals were epithelial cell activity markers and antibody components. A variety of peptidases, such as aminopeptidase Ey (AMPN) and angiotensin-converting enzyme (ACE), are localized in the intestinal brush border membrane and are involved as major functional enzymes in the final stage of protein digestion in the small intestine [59]. In case of bacterial infection, epithelial cells could be damaged with loss of the functional brush border membrane. In rats, the distribution of ACE activity is highest in the proximal to middle region of the intestine, decreasing distally [59]. In our study, AMPN was annotated by more 
than 65 unique peptides, both in ileum and colon, while the average unique peptide level per protein was 6 . This indicates a high chance of detectability and stability of AMPN in intestinal content. It seems plausible that lower concentrations of brush border enzymes are found when less epithelial cells are present, thus in the intestinal content of challenged animals.

It is probable that following proteins are linked to highly metabolically active cells which results in a reduced abundance in case of gut health problems. Superoxide dismutase [Cu-Zn] (SOD) catalyzes the dismutation of superoxide radicals to hydrogen peroxide $\left(\mathrm{H}_{2} \mathrm{O}_{2}\right)$ and oxygen and contributes to enhanced small intestinal preservation in animals [60]. Superoxide dismutases consist of three isoforms in mammals, namely the cytoplasmic, mitochondrial and extracellular $\mathrm{Cu}-\mathrm{Zn}$ SOD [61]. Chicken SOD has $71.2 \%, 14.8 \%$ and $24.4 \%$ identity respectively with the human isoforms suggesting that in our study the cytoplasmic isoform of chicken SOD was identified. Mitochondrial aspartate aminotransferase (AATM), formerly known as glutamic-oxaloacetic transaminase, catalyzes the reaction of $\mathrm{L}$-aspartate and 2-oxoglutarate to oxaloacetate and glutamate [62]. WD (tryptophan-aspartate) repeat-containing protein 1 (WDR1), also called actin-interacting protein 1 (AIP1), acts as a cofactor of ADF-cofilin and facilitates actin turnover by disassembly of actin filaments [63]. Lechuga [64] suggests that this protein is necessary for intestinal epithelial morphogenesis due to its abundance at epithelial apical junctions which was substantiated with the observation that downregulation of AIP1 expression increased paracellular permeability and reduced junctional recruitment of adherens and tight junction proteins. This is consistent with our data, showing a reduced abundance in the ileum of challenged birds. Cathepsin D (CATD), an aspartic proteinase expressed in lysosomes, is the second most abundant protease after pepsin in the chicken gastrointestinal tract [65], thus suggesting that, in chicken, CATD may play additional roles, other than just being a "housekeeping enzyme" necessary for autophagy [66]. It could play a role as a digestive enzyme, as has been suggested in fish [67].

Antibody light chain proteins were found less abundant in the ileal content of challenged animals compared to control animals. In birds, immunoglobulins IgA, IgM and IgY (also named chicken IgG) are antibodies produced by B-cells as a response to presented antigens and consist of two heavy and light chains whereby birds only have one isotope of light chain, namely lambda $(\lambda)$. The light chain is made up of a constant, Ig lambda chain C region (LAC), and a variable region, Ig lambda chain $\mathrm{V}-1$ region (LV1) [68]. IgAs are the most predominant class of antibodies in mucosal secretions with their primary function to maintain homeostasis at the mucosal surface and thus a steadystate condition in the gut [69]. However, the reason for lower abundance in challenged birds is not clear.

In conclusion, using a broiler gut inflammation model, we have identified candidate intestinal biomarkers in ileal and/or colonic content of which concentrations differed significantly between control and challenged animals. Ideal potential biomarkers should be highly discriminative between challenged and control groups, and have high but no overlapping numerical values between groups, to have a good chance of being applicable in the field. Since the model was developed using triggers that are common in field conditions, these potential biomarkers can serve as basis for validation in the field via development of easy and rapid diagnostic tools as a method to detect and measure gut barrier failure in broilers.

\section{Abbreviations}

AATM: mitochondrial aspartate aminotransferase; ACE: angiotensin-converting enzyme; ACTN4: alpha-actinin-4; ANXA5: annexin A5; APOA1: apolipoprotein A-1; BHI: brain heart infusion; BW: body weight; CATD: cathepsin D; CFU: colony-forming unit; DAB: di-amino-benzidine; DDA: data dependent acquisition; DFI: daily feed intake; DSS: dextran sulphate sodium; DTT: dithiothreitol; DWG: daily weight gain; FCR: feed conversion ratio; FINC: fibronectin; H2A4: histone H2A-IV; HBB: hemoglobin subunit beta; HPLC-MS: high performance liquid chromatography-mass spectrometry; IBD: inflammatory bowel disease; IOV7: ovoinhibitor; LAC: Ig lambda chain C region; LB: Luria-Bertani; LPS: lipopolysaccharide; LV1: Ig lambda chain V-1 region; MIM1: myeloid protein 1; MMTS: methanethiosulfonate; MRS: Man-Rogosa-Sharpe; NPM: nucleophosmin; NSP: non-starch polysaccharides; PBS: phosphate buffered saline; RET4: retinolbinding protein 4; SOD: superoxide dismutase [Cu-Zn]; TTR: transthyretin; WDR1:WD repeat-containing protein 1.

\section{Acknowledgements}

The authors would like to thank Christian Puttevils and Delphine Ameye for their skillful technical assistance.

\section{Authors' contributions}

Study design: $F D M, V E$, RD, MDG, FVI; Animal experiments: FDM, VE, AD; in vitro experiments: FDM, MD, SD; Preparation of the manuscript: FDM, VE, RD, MD, $\mathrm{SD}, \mathrm{FH}, \mathrm{DD}, \mathrm{FVI}$. All authors offered a critical review of the manuscript. All authors read and approved the final manuscript.

\section{Funding}

This work was funded by Flanders Innovation \& Entrepreneurship, a regional governmental agency.

\section{Ethics approval and consent to participate}

The experiment was approved by the Ethical Committee of Poulpharm BVBA, Izegem, Belgium (bacterial enteritis trial; P1606-FP) with approval number LA1400564. The animal experiment was carried out in accordance with approved guidelines.

\section{Competing interests}

F De Meyer, V. Eeckhaut, R. Ducatelle and F. Van Immerseel are listed as coinventors on a patent application for intestinal and fecal biomarkers for intestinal health in poultry (International Application Number EP19162944.3).

\section{Author details}

${ }^{1}$ Department of Pathology, Bacteriology and Avian Diseases, Faculty of Veterinary Medicine, Ghent University, Salisburylaan 133, 9820 Merelbeke, Belgium. ${ }^{2}$ Laboratory for Pharmaceutical Biotechnology, Faculty of Pharmaceutical Sciences, Ghent University, Ottergemsesteenweg 460, 9000 Ghent, Belgium. 
${ }^{3}$ Poulpharm BVBA, Prins Albertlaan 112, 8870 Izegem, Belgium. ${ }^{4}$ Vetworks BVBA, Knokstraat 38, 9880 Poeke, Belgium.

Received: 19 March 2019 Accepted: 27 May 2019

Published online: 18 June 2019

\section{References}

1. Scanes CG (2007) The global importance of poultry. Poult Sci 86:1057-1058

2. Cowieson AJ, Selle PH (2012) The evnironmental impact of low feed conversion ratios in poultry. https://en.engormix.com/poultry-industry/ articles/impact-of-low-feed-conversion-ratios-in-poultry-t34854.htm. Accessed 15 Jan 2019

3. Wu G, Bazer FW, Cross HR (2014) Land-based production of animal protein: impacts, efficiency, and sustainability. Ann N Y Acad Sci 1328:18-28

4. Bailey RA (2010) Intestinal microbiota and the pathogenesis of dysbacteriosis in broiler chickens. Ph.D. Thesis, Institute of Food Research, University of East Anglia

5. Dunlop MW, Moss AF, Groves PJ, Wilkinson SJ, Stuetz RM, Selle PH (2016) The multidimensional causal factors of "wet litter" in chicken-meat production. Sci Total Environ 562:766-776

6. Yegani M, Korver DR (2008) Factors affecting intestinal health in poultry. Poult Sci 87:2052-2063

7. Sugiharto S (2016) Role of nutraceuticals in gut health and growth performance of poultry. J Saudi Soc Agric Sci 15:99-111

8. Song J, Xiao K, Ke YL, Jiao LF, Hu CH, Diao QY, Shi B, Zou XT (2014) Effect of a probiotic mixture on intestinal microflora, morphology, and barrier integrity of broilers subjected to heat stress. Poult Sci 93:581-588

9. Williams JM, Duckworth CA, Burkitt MD, Watson AJM, Campbell BJ, Pritchard DM (2015) Epithelial cell shedding and barrier function. Vet Pathol 52:445-455

10. Chen J, Tellez G, Richards JD, Escobar J (2015) Identification of potential biomarkers for gut barrier failure in broiler chickens. Front Vet Sci 2:14

11. Awad WA, Hess C, Hess M (2017) Enteric pathogens and their toxininduced disruption of the intestinal barrier through alteration of tight junctions in chickens. Toxins (Basel) 9:E60

12. Awad WA, Ghareeb K, Abdel-Raheem S, Bohm J (2009) Effects of dietary inclusion of probiotic and synbiotic on growth performance, organ weights, and intestinal histomorphology of broiler chickens. Poult Sci 88:49-56

13. Morampudi V, Bhinder G, Wu X, Dai C, Sham HP, Vallance BA, Jacobson $K$ (2014) DNBS/TNBS colitis models: providing insights into inflammatory bowel disease and effects of dietary fat. J Vis Exp 84:e51297

14. Wideman RF (2016) Bacterial chondronecrosis with osteomyelitis and lameness in broilers: a review. Poult Sci 95:325-344

15. Persoons D, Dewulf J, Smet A, Herman L, Heyndrickx M, Martel A, Catry B, Butaye P, Haesebrouck F (2012) Antimicrobial use in Belgian broiler production. Prev Vet Med 105:320-325

16. Cervantes HM (2015) Antibiotic-free poultry production: is it sustainable? J Appl Poult Res 24:91-97

17. De Gussem M (2010) Macroscopic scoring system for bacterialenteritis in broiler chickens and turkeys. In: WVPA Meeting 01/04/2010. Merelbeke, Belgium. https://www.researchgate.net/publication/330410274_Macro scopic_scoring_system_for_bacterial_enteritis_in_broiler_chickens_ and_turkeys. Accessed 26 Feb 2019

18. Ducatelle R, Goossens E, De Meyer F, Eeckhaut V, Antonissen G, Haesebrouck F, Van Immerseel F (2018) Biomarkers for monitoring intestinal health in poultry: present status and future perspectives. Vet Res 49:43

19. Canani RB, Terrin G, Rapacciuolo L, Miele E, Siani MC, Puzone C, Cosenza L, Staiano A, Troncone R (2008) Faecal calprotectin as reliable non-invasive marker to assess the severity of mucosal inflammation in children with inflammatory bowel disease. Dig Liver Dis 40:547-553

20. Chang MH, Chou JW, Chen SM, Tsai MC, Sun YS, Lin CC, Lin CP (2014) Faecal calprotectin as a novel biomarker for differentiating between inflammatory bowel disease and irritable bowel syndrome. Mol Med Rep 10:522-526

21. Gilani S, Howarth GS, Kitessa SM, Tran CD, Forder REA, Hughes RJ (2016) Intestinal permeability induced by lipopolysaccharide and measured by lactulose, rhamnose and mannitol sugars in chickens. Animal 11:1174-1179

22. Goossens E, Debyser G, Callens C, De Gussem M, Dedeurwaerder A, Devreese B, Haesebrouck F, Flügel M, Pelzer S, Thiemann F, Ducatelle R, Van Immerseel F (2018) Elevated faecal ovotransferrin concentrations are indicative for intestinal barrier failure in broiler chickens. Vet Res 49:51

23. Miyazaki K, Martin JC, Marinsek-Logar R, Flint HJ (1997) Degradation and utilization of xylans by the rumen anaerobe Prevotella bryantii (formerly $P$. ruminicola subsp. brevis) B(1)4. Anaerobe 3:373-381

24. Johnson J, Reid WM (1970) Anticoccidial drugs: lesion scoring techniques in battery and floor-pen experiments with chickens. Exp Parasitol 28:30-36

25. De Maesschalck C, Eeckhaut V, Maertens L, De Lange L, Marchal L, Nezer C, De Baere S, Croubels S, Daube G, Dewulf J, Haesebrouck F, Ducatelle R, Taminau B, Van Immerseel F (2015) Effects of xylo-oligosaccharides on broiler chicken performance and microbiota. Appl Environ Microbiol 81:5880-5888

26. De Gussem M (2007) Coccidiosis in poultry: review on diagnosis, control, prevention and interaction with overall gut health. In: Proceedings of the 16th European symposium on poultry nutrition, Strasbourg, 26-30 August 2007, pp 253-261

27. Pop L, Györke A, Tăbăran AF, Dumitrache MO, Kalmár Z, Magdaş C, Mircean V, Zagon D, Balea A, Cozma V (2015) Effects of artemisinin in broiler chickens challenged with Eimeria acervulina, E. maxima and E. tenella in battery trials. Vet Parasitol 214:264-271

28. Kuttappan VA, Vicuña EA, Latorre JD, Wolfenden AD, Téllez GI, Hargis BM, Bielke LR (2015) Evaluation of gastrointestinal leakage in multiple enteric inflammation models in chickens. Front Vet Sci 2:66

29. Hall AB, Yassour M, Sauk J, Garner A, Jiang X, Arthur T, Lagoudas GK Vatanen T, Fornelos N, Wilson R, Bertha M, Cohen M, Garber J, Khalili H, Gevers D, Ananthakrishnan AN, Kugathasan S, Lander ES, Blainey P, Vlamakis H, Xavier RJ, Huttenhower C (2017) A novel Ruminococcus gnavus clade enriched in inflammatory bowel disease patients. Genome Med 9:103

30. Berstad A, Raa J, Midtvedt T, Valeur J (2016) Probiotic lactic acid bacteria-the fledgling cuckoos of the gut? Microb Ecol Health Dis 27:10

31. Stanley D, Wu S-B, Rodgers N, Swick RA, Moore RJ (2014) Differential responses of cecal microbiota to fishmeal, Eimeria and Clostridium perfringens in a necrotic enteritis challenge model in chickens. PLoS One 9:e104739

32. Gilani S, Howarth GS, Kitessa SM, Tran CD, Forder REA, Hughes RJ (2017) New biomarkers for increased intestinal permeability induced by dextran sodium sulphate and fasting in chickens. J Anim Physiol Anim Nutr (Berl) 101:e237-e245

33. Allen SCH, Hebbes TR (2003) Myb induced myeloid protein 1 (Mim-1) is an acetyltransferase. FEBS Lett 534:119-124

34. Derikx JP, Luyer MD, Heineman E, Buurman WA (2010) Non-invasive markers of gut wall integrity in health and disease. World J Gastroenterol 16:5272-5279

35. Leick M, Azcutia V, Newton G, Luscinskas FW (2014) Leukocyte recruitment in inflammation: basic concepts and new mechanistic insights based on new models and microscopic imaging technologies. Cell Tissue Res 355:647-656

36. Bischoff SC, Barbara G, Buurman W, Ockhuizen T, Schulzke J-D, Serino M, Tilg H, Watson A, Wells JM (2014) Intestinal permeability_a new target for disease prevention and therapy. BMC Gastroenterol 14:189

37. Bjarnason I (2017) The use of fecal calprotectin in inflammatory bowel disease. Gastroenterol Hepatpol 13:53-56

38. Pankov R, Yamada KM (2002) Fibronectin at a glance. J Cell Sci 115:3861-3863

39. Kolachala VL, Bajaj R, Wang L, Yan Y, Ritzenthaler JD, Gewirtz AT, Roman J, Merlin D, Sitaraman SV (2007) Epithelial-derived fibronectin expression, signaling, and function in intestinal inflammation. J Biol Chem 282:32965-32973

40. Bönisch C, Hake SB (2012) Histone H2A variants in nucleosomes and chromatin: more or less stable? Nucleic Acids Res 40:10719-10741

41. Zou T, Rao JN, Liu L, Marasa BS, Keledjian KM, Zhang A-H, Xiao L, Bass BL, Wang J-Y (2005) Polyamine depletion induces nucleophosmin modulating stability and transcriptional activity of p53 in intestinal epithelial cells. Am J Physiol Cell Physiol 289:686-696 
42. Dhar SK, St Clair DK (2009) Nucleophosmin blocks mitochondrial localization of p53 and apoptosis. J Biol Chem 284:16409-16418

43. Parker A, Maclaren OJ, Fletcher AG, Muraro D, Kreuzaler PA, Byrne HM, Maini PK, Watson AJM, Pin C (2017) Cell proliferation within small intestinal crypts is the principal driving force for cell migration on villi. FASEB J 31:636-649

44. Odenwald MA, Turner JR (2017) The intestinal epithelial barrier: a therapeutic target? Nat Rev Gastroenterol Hepatol 14:9-21

45. Craig SW, Pardo JV (1979) Alpha-actinin localization in the junctional complex of intestinal epithelial cells. J Cell Biol 80:203-210

46. Chen VC, Li X, Perreault H, Nagy JI (2006) Interaction of zonula occludens-1 (ZO-1) with r-actinin-4: application of functional proteomics for identification of PDZ domain-associated proteins. J Proteome Res 5:2123-2134

47. Milanini J, Fayad R, Partisani M, Lecine P, Borg J-P, Franco M, Luton F (2017) EFA6 regulates lumen formation through alpha-actinin 1. J Cell Sci 131:jcs209361

48. Lerner A, Matthias T (2015) Changes in intestinal tight junction permeability associated with industrial food additives explain the rising incidence of autoimmune disease. Autoimmun Rev 14:479-489

49. Jain S, Gautam V, Naseem S (2011) Acute-phase proteins: as diagnostic tool. J Pharm Bioallied Sci 3:118-127

50. O'Reilly EL (2016) Acute phase proteins and biomarkers for health in chickens. Ph.D. Thesis, Institute of Biodiversity, Animal Health and Comparative Medicine, College of Medical Veterinary and Life Sciences

51. Mangaraj M, Nanda R, Panda S (2015) Apolipoprotein A-l: a molecule of diverse function. Indian J Clin Biochem 31:253-259

52. Doherty MK, Mclean L, Hayter JR, Pratt JM, Robertson DHL, El-Shafei A, Gaskell SJ, Beynon RJ (2004) The proteome of chicken skeletal muscle: changes in soluble protein expression during growth in a layer strain. Proteomics 4:2082-2093

53. Glickman RM, Green PHR (1977) The intestine as a source of apolipoprotein Al. Proc Natl Acad Sci U S A 74:2569-2573

54. Ingenbleek $Y$, Bernstein LH (2015) Plasma transthyretin as a biomarker of lean body mass and catabolic states. Adv Nutr 6:572-580

55. Thomas S, Prabhu R, Balasubramanian KA (2018) Retinoid metabolism in the rat small intestine. $\mathrm{Br} J$ Nutr 93:59-63

56. Andersen CJ (2015) Bioactive egg components and inflammation. Nutrients 7:7889-7913

57. Munoz LE, Franz S, Pausch F, Fürnrohr B, Sheriff A, Vogt B, Kern PM, Baum W, Stach C, Von Laer D, Brachvogel B, Poschl E, Herrmann M, Gaipl US (2007) The influence on the immunomodulatory effects of dying and dead cells of Annexin V. J Leukoc Biol 81:6-14
58. Van Genderen HO, Kenis H, Hofstra L, Narula J, Reutelingsperger CPM (2008) Extracellular annexin A5: functions of phosphatidylserine-binding and two-dimensional crystallization. Biochim Biophys Acta 1783:953-963

59. Yoshioka M, Erickson RH, Woodley JF, Gulli R, Guan D, Kim YS (1987) Role of rat intestinal brush-border membrane angiotensin-converting enzyme in dietary protein digestion. Am J Physiol 253:G781-G786

60. Sun SC, Greenstein SM, Schechner RS, Sablay LB, Veith FJ, Tellis VA (1992) Superoxide dismutase: enhanced small intestinal preservation. J Surg Res 52:583-590

61. Fukai T, Ushio-Fukai M (2011) Superoxide dismutases: role in redox signaling, vascular function, and diseases. Antioxid Redox Signal 15:1583-1606

62. Kaneko JJ, Harvey JW, Bruss ML, Hoffmann WE, Solter PF (2008) Diagnostic enzymology of domestic animals. Clin Biochem Domest Anim 6:351-378

63. Fujibuchi T, Abe Y, Takeuchi T, Imai Y, Kamei Y, Murase R, Ueda N, Shigemoto K, Yamamoto H, Kito K (2004) AIP1/WDR1 supports mitotic cell rounding. Biochem Biophys Res Commun 327:268-275

64. Lechuga S, Baranwal S, Ivanov Al (2015) Actin-interacting protein 1 controls assembly and permeability of intestinal epithelial apical junctions. Am J Physiol Gastrointest Liver Physiol 308:G745-G756

65. Jamdar SN, Harikumar P (2016) Purification, identification and characterization of aspartic proteases of chicken intestine. J Food Biochem 40:451-462

66. Oliveira C, Pereira H, Alves S, Castro L, Baltazar F, Chaves SR, Preto A, Côrte-Real M (2015) Cathepsin D protects colorectal cancer cells from acetate-induced apoptosis through autophagy-independent degradation of damaged mitochondria. Cell Death Dis 6:e1788

67. Kuz'mina W, Ushakova NV (2010) The dependence on temperature and $\mathrm{pH}$ of the effects of zinc and copper on proteolytic activities of the digestive tract mucosa in piscivorous fish and their potential preys. Fish Physiol Biochem 36:787-795

68. Benčina M, Cizelj I, Berčič RL, Narat M, Benčina D, Dovč P (2014) Shared epitopes of avian immunoglobulin light chains. Vet Immunol Immunopathol 158:175-181

69. Suzuki K, Nakajima A (2014) New aspects of IgA synthesis in the gut. Int Immunol 26:489-494

\section{Publisher's Note}

Springer Nature remains neutral with regard to jurisdictional claims in published maps and institutional affiliations.
Ready to submit your research? Choose BMC and benefit from:

- fast, convenient online submission

- thorough peer review by experienced researchers in your field

- rapid publication on acceptance

- support for research data, including large and complex data types

- gold Open Access which fosters wider collaboration and increased citations

- maximum visibility for your research: over 100M website views per year

At BMC, research is always in progress.

Learn more biomedcentral.com/submissions 